\title{
Green synthesis of NiFe LDH/Ni foam at room temperature for highly efficient electrocatalytic oxygen evolution reaction
}

\author{
Hongchao Yang ${ }^{1,2}$, Changhong Wang ${ }^{1,2}$, Yejun Zhang ${ }^{2}$ and Qiangbin Wang ${ }^{1,2^{*}}$
}

ABSTRACT Clean energy technologies such as water splitting and fuel cells have been intensively pursued in the last decade for their free pollution. However, there is plenty of fossil energy consumed in the preparation of the catalysts, which results in a heavy pollution. Therefore, it is much desired but challenging to fabricate high-efficiency catalysts without extra energy input. Herein, we used a facile one-pot room-temperature method to synthesize a highly efficient electrocatalyst of nickel iron layered double hydroxide grown on $\mathrm{Ni}$ foam (NiFe $\mathrm{LDH} / \mathrm{NF}$ ) for oxygen evolution reaction (OER). The formation of the NiFe LDH follows a dissolutionprecipitation process, in which the acid conditions by hydrolysis of $\mathrm{Fe}^{3+}$ combined with $\mathrm{NO}_{3}{ }^{-}$could etch the $\mathrm{NF}$ to form $\mathrm{Ni}^{2+}$. Then, the obtained $\mathrm{Ni}^{2+}$ was co-precipitated with the hydrolysed $\mathrm{Fe}^{3+}$ to in situ generate NiFe LDH on the NF. The NiFe LDH/NF exhibits excellent OER performance with a low potential of about $1.411 \mathrm{~V}$ vs. reversible hydrogen electrode (RHE) at a current density of $10 \mathrm{~mA} \mathrm{~cm}{ }^{-2}$, a small Tafel slope of $42.3 \mathrm{mV} \mathrm{dec}^{-1}$ and a significantly low potential of $\sim 1.452 \mathrm{~V}$ vs. RHE at $100 \mathrm{~mA} \mathrm{~cm}^{-2}$ in $1 \mathrm{~mol} \mathrm{~L}^{-1} \mathrm{KOH}$. Moreover, the material also keeps its original morphology and structure over $20 \mathrm{~h}$. This energy-efficient strategy to synthesize NiFe LDH is highly promising for widespread application in OER catalyst industry.

Keywords: green synthesis, nickel iron layered double hydroxide, room temperature, electrocatalyst, oxygen evolution reaction (OER)

\section{INTRODUCTION}

The massive fossil consumption has caused increasing environmental pollution and global warming, which has stimulated extensive research on many alternative sustainable and green energy carriers, for instance, water splitting and fuel cells [1,2]. In order to achieve high energy conversion and storage efficiency, substantial efforts have been made for rational design of electrocatalysts to reduce the overpotential of electrode reactions [3-5]. An appropriate electrocatalyst should possess outstanding catalytic activity and environmental friendliness [6-10]. Besides, the cost of catalyst also has to be considered, including material and the manufacturing cost. The noble-metal based materials are unfit for practical applications due to their high price and low reservation, although they present the state-of-the-art electrocatalytic performance [11-13]. Up to now, many noble-metal-free materials were designed to give excellent catalytic activities for these electrochemical processes to improve their energy conversion efficiency [14-16]. Nevertheless, their preparation procedure needs to input high cost and leads to a vicious cycle, which hinders their applications in reality. Therefore, it is urgent to develop a green synthetic strategy for non-noble-metal electrocatalysts with high efficiency without extra energy input.

Various non-precious metal materials, such as first-row transition metal oxide, hydroxide and their derivatives, have been extensively studied as electrocatalytic catalysts/ precatalysts for oxygen evolution reaction (OER) due to their excellent performance and high reserves [17-24]. Among them, nickel iron-based materials (e.g., NiFe layered double hydroxide (NiFe $\mathrm{LDH}), \mathrm{NiFe}$ hydroxide, $\mathrm{NiFe}$ oxide) have been regarded as one of the most efficient noble-metal-free alternatives towards OER in alkaline media [25-32]. To synthesize these catalysts, the

\footnotetext{
${ }^{1}$ School of Nano Technology and Nano Bionics, University of Science and Technology of China, Hefei 230026, China

${ }^{2}$ Key Laboratory of Nano-Bio Interface, Division of Nanobiomedicine and i-Lab, Suzhou Institute of Nano-Tech and Nano-Bionics, Chinese Academy of Sciences, Suzhou 215123, China

* Corresponding author (email: qbwang2008@sinao.ac.cn)
} 
conventional methods mainly include hydrothermal/solvothermal, co-precipitation and electrolytic deposition. For instance, Liu et al. [33] used hydrothermal method to synthesize single-crystalline $\mathrm{Fe}-\mathrm{Ni}(\mathrm{OH})_{2}$ nanoflake arrays on $\mathrm{Ni}$ foam $(\mathrm{NF})$, showing self-activated electrocatalysis for OER. Gong and co-workers [34] reported a NiFe LDH nanoplate/CNT complex for advanced OER electrocatalysis by solvothermal method. Qi et al. [35] synthesized porous nickel-iron oxide via co-precipitation reaction at $60^{\circ} \mathrm{C}$, which exhibited highly efficient OER performance. Lu et al. [36] prepared amorphous NiFe hydroxide nanosheets on $\mathrm{Ni}$ foam via electrodeposition as efficient OER electrode. However, all these approaches require extra energy replenishment, which costs a lot and runs counter to green energy. Consequently, it is necessary to exploit new cost-effective strategies to synthesize high-efficiency NiFe based materials without extra energy supply. Furthermore, the transitional-metal-based electrocatalysts usually combine with polymer binders like Nafion as electrodes, which results in poor conductivity and inferior mechanical stability [35,37]. A feasible solution is to directly grow active electrocatalysts on conductive substrate such as $\mathrm{Ni}$ foam (NF) as electrode.

Herein, we used a facile one-pot room-temperature method without any extra energy input to synthesize nickel iron layered double hydroxide grown on $\mathrm{NF}$ ( NiFe $\mathrm{LDH} / \mathrm{NF}$ ). And the as-prepared $\mathrm{NiFe} \mathrm{LDH} / \mathrm{NF}$ was directly used as working electrode and exhibited excellent OER performance with a potential of about $1.411 \mathrm{~V} v s$. reversible hydrogen electrode (RHE) at a current density of $10 \mathrm{~mA} \mathrm{~cm}^{-2}$, a small Tafel slope of $42.3 \mathrm{mV} \mathrm{dec}^{-1}$ and a significantly low potential of $\sim 1.452 \mathrm{~V} v s$. RHE at $100 \mathrm{~mA} \mathrm{~cm}^{-2}$ in $1 \mathrm{~mol} \mathrm{~L}^{-1} \mathrm{KOH}$ and remained its original morphology and structure over $20 \mathrm{~h}$.

\section{EXPERIMENTAL SECTION}

\section{Chemicals}

All chemicals were used as received without further purification. Iron (III) nitrate nonahydrate (AR $\geq 99.0 \%$ ), iron (III) chloride hexahydrate (AR $\geq 99.0 \%$ ), nickel nitrate hexahydrate (AR $\geq 98.0 \%$ ), hydrochloric acid (36 wt.\% in $\mathrm{H}_{2} \mathrm{O}$ ) and ethanol (AR, anhydrous, $\geq 99.7 \%$ ) were of analytical grade and obtained from Sinopharm Chemical Reagent Co., Ltd. KOH solution (HPLC, 45 wt.\% in $\mathrm{H}_{2} \mathrm{O}$ ) was purchased from Sigma-Aldrich. Ruthenium (IV) dioxide (metal basis, 99.9\%) was purchased from Alfa Aesar. The deionized water for the experiments was purified through a Millipore system.

\section{Synthesis of NiFe LDH/NF}

Typically, a piece of NF $(2 \mathrm{~cm} \times 3 \mathrm{~cm})$ was precleaned in $5 \mathrm{~mol} \mathrm{~L}^{-1} \mathrm{HCl}$ under sonication, and then washed with water and ethanol. Then, $60 \mathrm{mg} \mathrm{Fe}\left(\mathrm{NO}_{3}\right)_{3} \cdot 9 \mathrm{H}_{2} \mathrm{O}$ was dissolved in a mixture of $15 \mathrm{~mL}$ deionized water and $5 \mathrm{~mL}$ ethanol under continuous stirring for $5 \mathrm{~min}$. Subsequently, the prepared NF was immersed in the above solution and left undisturbed at room temperature for $24 \mathrm{~h}$. Then, the products were obtained and washed with deionized water for several times. Loading amount of the $\mathrm{NiFe} \mathrm{LDH}$ in $\mathrm{NiFe} \mathrm{LDH} / \mathrm{NF}$ is about $0.51 \mathrm{mg} \mathrm{cm}^{-2}$ according to the inductively coupled plasma mass spectrometry (ICP-MS) technology.

\section{Synthesis of $\mathrm{Ni}(\mathrm{OH})_{2} / \mathrm{NF}$}

To prepare $\mathrm{Ni}(\mathrm{OH})_{2} / \mathrm{NF}, 87 \mathrm{mg} \mathrm{Ni}\left(\mathrm{NO}_{3}\right)_{2} \cdot 6 \mathrm{H}_{2} \mathrm{O}$ was dissolved in a mixture of $30 \mathrm{~mL}$ deionized water and $10 \mathrm{~mL}$ ethanol under continuous stirring for $5 \mathrm{~min}$. Subsequently, the solution was transferred into a $50 \mathrm{~mL}$ Teflon-lined stainless steel autoclave and the prepared NF was immersed in it to react at $180^{\circ} \mathrm{C}$ for $6 \mathrm{~h}$. The $\mathrm{Ni}(\mathrm{OH})_{2}$ loading amount of $\mathrm{Ni}(\mathrm{OH})_{2} / \mathrm{NF}$ is about $2.13 \mathrm{mg} \mathrm{cm}^{-2}$.

\section{Characterization}

The morphologies of the products were characterized through a Tecnai G2 F20 S-Twin transmission electron microscope (TEM) at an acceleration voltage of $200 \mathrm{kV}$, and a Quanta 400 FEG scanning electron microscope (SEM) at $20 \mathrm{kV}$, respectively. Energy-dispersive spectroscopy (EDS) and high resolution TEM (HR-TEM) were also recorded on Tecnai G2 F20 S-TEM. Atomic force microscopy (AFM) images were obtained on an ICON Bruker instrument operating in ScanAsyst mode at room temperature. Powder X-ray diffraction (XRD) patterns were recorded on a Bruker D8 Advance powder X-ray diffractometer at a scanning rate of $4^{\circ} \mathrm{min}^{-1}$, using $\mathrm{Cu}$ Ka radiation $(\lambda=1.54056 \AA)$. X-ray photoelectron spectroscopy (XPS) data were performed by a PHI 5000 Versaprobe X-ray photoelectron spectrometer, using nonmonochromatized Al-Ka X-ray as the excitation source. ICP-MS technology was recorded on Thermo Fisher Scientific ICAP Qc.

\section{Electrochemical measurement}

Synthesis of $\mathrm{RuO}_{2} / \mathrm{NF}$ electrode: $5 \mathrm{mg} \mathrm{RuO}_{2}$ powder and $32 \mu \mathrm{L}$ of $5 \mathrm{wt} . \%$ Nafion solution were dispersed in $0.968 \mathrm{~mL}$ of $4: 1(\mathrm{~V} / \mathrm{V})$ water/ethanol by sonication for at least $30 \mathrm{~min}$ to form a homogeneous ink. Then $50 \mu \mathrm{L}$ of the catalyst ink (containing $0.25 \mathrm{mg}$ of $\mathrm{RuO}_{2}$ catalyst) was loaded onto a $1 \mathrm{~cm} \times 1 \mathrm{~cm} \mathrm{NF}$. 
The OER tests were carried out in a three electrode electrochemical cell by using CHI660E with an $\mathrm{Ag} / \mathrm{AgCl}$ $\left(3 \mathrm{~mol} \mathrm{~L}^{-1} \mathrm{KCl}\right.$ ) electrode as the reference electrode and a Pt foil electrode as the counter electrode in $1 \mathrm{~mol} \mathrm{~L}^{-1}$ KOH. $1 \mathrm{~cm} \times 1 \mathrm{~cm} \mathrm{NiFe} \mathrm{LDH/NF,} \mathrm{Ni}(\mathrm{OH})_{2} / \mathrm{NF}, \mathrm{RuO}_{2} / \mathrm{NF}$ and bare NF were investigated as the working electrode. Linear scanning voltammetry (LSV) was carried out at a scan rate of $2 \mathrm{mV} \mathrm{s}^{-1}$. Electrochemical impedance spectroscopy (EIS) was recorded in the frequency range of $0.1 \mathrm{~Hz}$ to $100 \mathrm{kHz}$ with an amplitude of $5 \mathrm{mV}$. All the potentials reported in this work are with $95 \% i R$ correction, which are given versus $\mathrm{RHE}$ according to $E_{v s \text {. RHE }}=$ $E_{v s . \mathrm{Ag} / \mathrm{AgCl}}+E_{\mathrm{Ag} / \mathrm{AgCl}}^{\theta}+0.059 \mathrm{pH}$.

Faradaic efficiency: Assuming that four electrons are needed to produce one $\mathrm{O}_{2}$ molecule, the Faradaic efficiency $(\eta)$ can be calculated as follows:

$\eta=4 \times F \times n_{\mathrm{O}_{2}} / Q$,

where $F$ is the Faraday constant. $n_{\mathrm{O}_{2}}$ is the number of moles of total produced $\mathrm{O}_{2}$, which was measured using drainage gas gathering method. $Q$ is the total charge passed through the cell: $Q=I \cdot t(\mathrm{C})$, where $I$ and $t$ are the constant oxidation current (A) and time (s).

\section{RESULTS AND DISCUSSION}

The NiFe LDH/NF was synthesized via a simple one-pot room-temperature method shown in Fig. 1a. Typically, a piece of NF after acid treatment was immersed in a $\mathrm{H}_{2} \mathrm{O}$ / ethanol solution containing $\mathrm{Fe}\left(\mathrm{NO}_{3}\right)_{3}$, and left undisturbed at room temperature for $24 \mathrm{~h}$, then the $\mathrm{NiFe}$ LDH/NF was obtained. The morphology of the NiFe $\mathrm{LDH} / \mathrm{NF}$ was carefully characterized. As shown in Fig. $1 \mathrm{~b}$ and Fig. S1, the SEM images reveal that the well-aligned $\mathrm{NiFe}$ LDH arrays are laid on the NF. And the TEM image in Fig. 1c details the NiFe LDH with ultrathin film structure, presented by the AFM image in Fig. S2. An HRTEM image in Fig. 1d features that the NiFe LDH has an interplane distance of the lattice fringe of $0.25 \mathrm{~nm}$, which corresponds to that of the (012) facet of NiFe LDH. Then, the powder XRD pattern of the NiFe LDH/NF was characterized. As displayed in Fig. S3, only Ni foam peaks could be found and the signal of NiFe LDH was undetectable which was ascribed to the very thin NiFe LDH film on NF substrate. Then, the NiFe LDH was scraped off the substrate and collected to measure its crystal phase. In Fig. 1e, the XRD pattern presents the major diffraction peaks at $11.4^{\circ}, 23.6^{\circ}, 34.5^{\circ}, 60.3^{\circ}$, which can be indexed to the (003), (006), (012), and (110) facets of the hydrotalcite-like NiFe LDH [38]. The EDS (Fig. S4) was further executed to demonstrate the presence of $\mathrm{Ni}, \mathrm{Fe}$
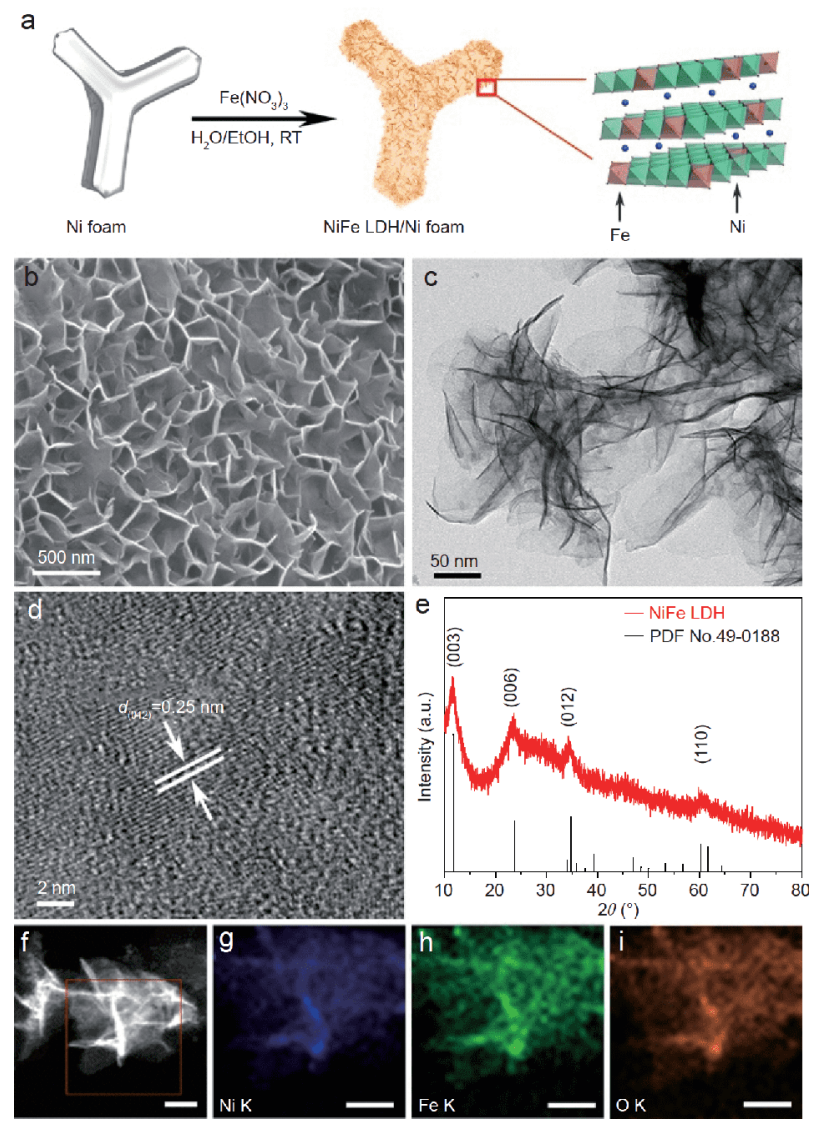

Figure 1 (a) The synthetic process of $\mathrm{NiFe} \mathrm{LDH} / \mathrm{NF}$ at room temperature. Characterization of the NiFe LDH, (b) SEM image, (c) TEM image, (d) HRTEM image, (e) XRD pattern, (f-i) HAADF STEM image and EDS element mappings. Scale bar: $50 \mathrm{~nm}$. The NiFe LDH sample for XRD pattern, TEM, and EDS element mappings was scraped off the substrate and dispersed in ethanol ultrasonically.

and O. And the high-resolution high-angle annular darkfield (HAADF) STEM image and the corresponding EDS element mapping of the sample in Fig. 1f-i illustrate that the $\mathrm{Ni}, \mathrm{Fe}$ and $\mathrm{O}$ were homogeneously distributed in the $\mathrm{NiFe}$ LDH. In order to evaluate the electrocatalytic activity of $\mathrm{NiFe} \mathrm{LDH} / \mathrm{NF}$, a control sample of $\mathrm{Ni}(\mathrm{OH})_{2}$ nanosheet on $\mathrm{NF}\left(\mathrm{Ni}(\mathrm{OH})_{2} / \mathrm{NF}\right)$ was prepared as characterized in Figs S5-S7. The SEM images of the $\mathrm{Ni}(\mathrm{OH})_{2} /$ $\mathrm{NF}$ demonstrate the well-defined $\mathrm{Ni}(\mathrm{OH})_{2}$ nanosheet vertically grown on the NF. The HRTEM image and XRD pattern indicate that the sample is $\beta$-phase $\mathrm{Ni}(\mathrm{OH})_{2}$.

Further, the surface chemical states of the NiFe LDH/ NF were investigated by XPS. As depicted in Fig. 2a, the survey spectra confirm that the NiFe LDH/NF are composed of $\mathrm{Fe}, \mathrm{Ni}, \mathrm{O}$ and no Fe signal presents in $\mathrm{Ni}(\mathrm{OH})_{2} /$ NF, which highly agree with the EDS results. The high resolution $\mathrm{Fe} 2 \mathrm{p}$ region in Fig. $2 \mathrm{~b}$ exhibits three binding 

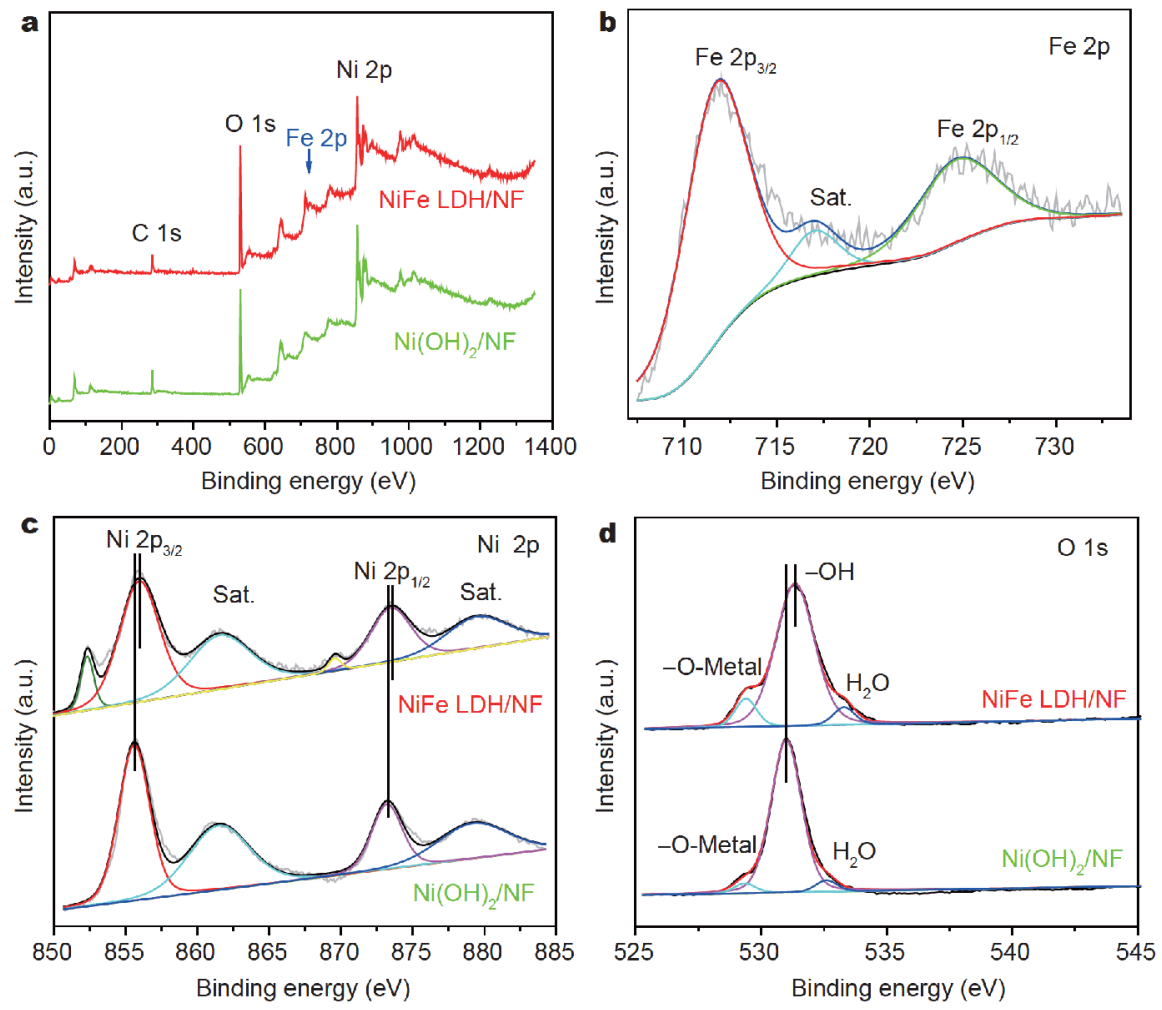

Figure 2 (a) XPS survey spectra of the NiFe LDH/NF and $\mathrm{Ni}(\mathrm{OH})_{2} / \mathrm{NF}$. (b) Deconvoluted high resolution Fe 2p region of the NiFe LDH/NF. (c) High resolution $\mathrm{Ni} 2 \mathrm{p}$ region of the $\mathrm{NiFe} \mathrm{LDH} / \mathrm{NF}$ and $\mathrm{Ni}(\mathrm{OH})_{2} / \mathrm{NF}$. (d) High resolution $\mathrm{O} 1$ s region of the $\mathrm{NiFe} \mathrm{LDH} / \mathrm{NF}$ and $\mathrm{Ni}(\mathrm{OH})_{2} / \mathrm{NF}$.

peaks at $711.9,724.9$ and $717.5 \mathrm{eV}$ belong to $\mathrm{Fe} 2 \mathrm{p}_{3 / 2}, \mathrm{Fe}$ $2 \mathrm{p}_{1 / 2}$ and satellite peaks, suggesting the +3 oxidation state of the Fe species in NiFe LDH/NF [35]. In Ni 2p spectrum of NiFe LDH/NF (Fig. 2c), the peaks at 855.8 and $873.5 \mathrm{eV}$ correspond to the $\mathrm{Ni}^{2+}$, accompanied by two prominent shakeup satellite peaks $(861.6$ and $879.5 \mathrm{eV}$ ). The peaks at 852.5 and $869.5 \mathrm{eV}$ belong to $\mathrm{Ni}^{\circ}$, emanating from the underlying NF substrate. Moreover, compared with $\mathrm{Ni}(\mathrm{OH})_{2} / \mathrm{NF}$, the $\mathrm{Ni} 2 \mathrm{p}_{3 / 2}$ and $\mathrm{Ni} 2 \mathrm{p}_{1 / 2}$ peaks in $\mathrm{NiFe}$ $\mathrm{LDH} / \mathrm{NF}$ shift to higher binding energy by about $0.4 \mathrm{eV}$, which is attributed to the electron transfer from the $\mathrm{Ni} \mathrm{d}$ band to the $\mathrm{Fe} \mathrm{d}$ band, indicating strong interaction between the $\mathrm{Fe}^{3+}$ and $\mathrm{Ni}^{2+}$ species in $\mathrm{NiFe} \mathrm{LDH} / \mathrm{NF}[35,37]$. In high-resolution $\mathrm{O}$ 1s spectrum of $\mathrm{NiFe} \mathrm{LDH} / \mathrm{NF}$ (Fig. 2d), the peaks at 529.4, 531.4 and $533.2 \mathrm{eV}$ are assigned to metal-O (Fe-O and $\mathrm{Ni}-\mathrm{O})$, metal-OH and adsorbed $\mathrm{H}_{2} \mathrm{O}$ species, respectively [37]. Compared with $\mathrm{Ni}(\mathrm{OH})_{2} / \mathrm{NF}$, the metal-OH peak in $\mathrm{NiFe} \mathrm{LDH} / \mathrm{NF}$ also exhibits a positive shift of about $0.4 \mathrm{eV}$, further suggesting the strong electron interaction between the $\mathrm{Fe}^{3+}$ and $\mathrm{Ni}^{2+}$ species in NiFe LDH/NF, which transforms the chemical state of oxygen and affects the binding energy of $\mathrm{O}$ 1s. This is conducive to improving the OER activity of the
$\mathrm{NiFe} \mathrm{LDH} / \mathrm{NF}$. Additionally, in $\mathrm{Ni} 2 \mathrm{p}$ region of the $\mathrm{Ni}(\mathrm{OH})_{2} / \mathrm{NF}$, the peaks of $\mathrm{Ni}^{0}$ disappeared because of the thick layer of covered $\mathrm{Ni}(\mathrm{OH})_{2}$ nanosheet on NF.

The growth mechanism of the NiFe LDH/NF follows a dissolution-precipitation process. It is known that $\mathrm{Fe}\left(\mathrm{NO}_{3}\right)_{3}$ are readily to hydrolyze in water, which makes the solution acidic ( $\mathrm{pH}=2.3$ in our system) (Equation 2) and etches the NF surface to form $\mathrm{Ni}^{2+}$ ions (Equation 3) based on the standard electrode potentials of $E^{\theta}\left(\mathrm{NO}_{3}{ }^{-}\right.$/ $\mathrm{NO})=0.96 \mathrm{~V}, E^{\theta}\left(\mathrm{Ni}^{2+} / \mathrm{Ni}\right)=-0.257 \mathrm{~V}$ [39]. The generated $\mathrm{Ni}^{2+}$ ions are then co-precipitated with $\mathrm{Fe}^{3+}$ ions to in situ form NiFe LDH on the NF (Equation 4). This synergy effect between $\mathrm{Fe}^{3+}$ and $\mathrm{Ni}^{2+}$ ions gives rise to the formation of NiFe LDH.

$$
\begin{aligned}
& \mathrm{Fe}^{3+}+(x+y) \mathrm{H}_{2} \mathrm{O} \rightarrow\left[\mathrm{Fe}(\mathrm{OH})_{x}\left(\mathrm{H}_{2} \mathrm{O}\right)_{y}\right]^{(3-x)+}+x \mathrm{H}^{+}, \\
& 3 \mathrm{Ni}+8 \mathrm{H}^{+}+2 \mathrm{NO}_{3}^{-} \rightarrow 3 \mathrm{Ni}^{2+}+2 \mathrm{NO}+4 \mathrm{H}_{2} \mathrm{O}, \\
& \mathrm{Ni}^{2+}+\left[\mathrm{Fe}(\mathrm{OH})_{x}\left(\mathrm{H}_{2} \mathrm{O}\right)_{y}\right]^{(3-x)+}+\mathrm{NO}_{3}^{-} \\
& +\mathrm{H}_{2} \mathrm{O} \rightarrow \mathrm{NiFeLDH} .
\end{aligned}
$$

It was noteworthy that the $\mathrm{NO}_{3}{ }^{-}$plays a crucial role in the formation of NiFe $\mathrm{LDH}$. When the $\mathrm{Fe}\left(\mathrm{NO}_{3}\right)_{3}$ change 

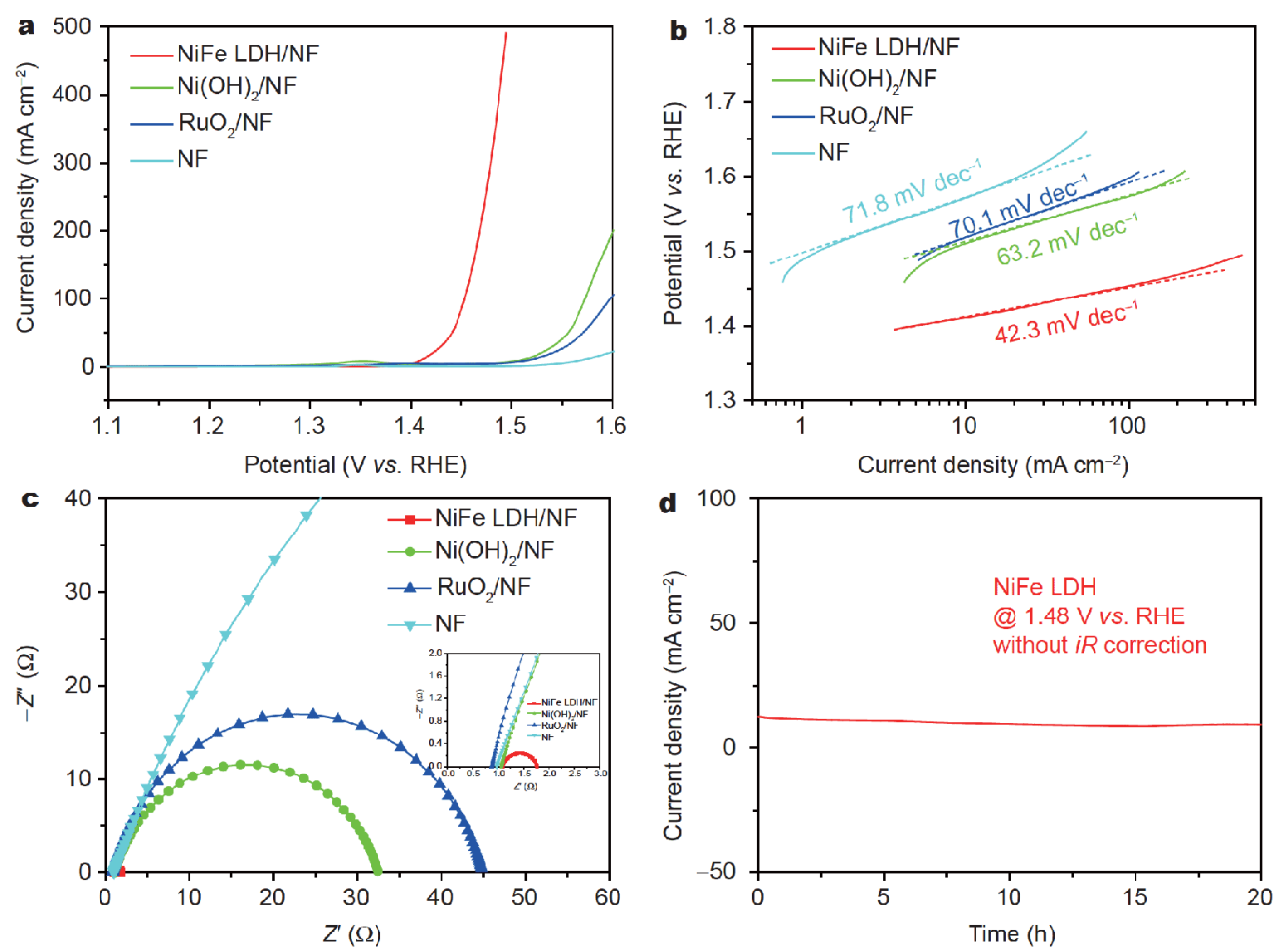

Figure 3 OER performance of the $\mathrm{NiFe} \mathrm{LDH} / \mathrm{NF}, \mathrm{Ni}(\mathrm{OH})_{2} / \mathrm{NF}, \mathrm{RuO}_{2} / \mathrm{NF}$ and bare NF. (a) The polarization curves at a scan rate of $2 \mathrm{mV} \mathrm{s}$ in $1 \mathrm{~mol} \mathrm{~L}^{-1} \mathrm{KOH}$. (b) The corresponding Tafel plots. (c) Nyquist plots at potential of $1.48 \mathrm{~V} v \mathrm{~s}$. RHE, inset: large-magnification Nyquist plots. (d) Chronoamperometric curve of NiFe LDH/NF at $\sim 1.48 \mathrm{~V} v s$. RHE without $i R$ correction.

to $\mathrm{FeCl}_{3}$, the NF remains its innate surface and no $\mathrm{NiFe}$ LDH forms under the same reaction conditions (Fig. S8). We deem that, although, the $E^{\theta}\left(\mathrm{Fe}^{3+} / \mathrm{Fe}^{2+}\right)$ of $0.771 \mathrm{~V}$ is larger than $E^{\theta}\left(\mathrm{Ni}^{2+} / \mathrm{Ni}\right)$ of $-0.257 \mathrm{~V}$, the strong coordination between $\mathrm{Cl}^{-}$and $\mathrm{Fe}^{3+}$ could suppress the growth of NiFe $\mathrm{LDH}$ on the NF with $\mathrm{FeCl}_{3}$ as Fe source. Moreover, the $\mathrm{NO}_{3}{ }^{-}$can also stabilize the NiFe LDH. In this $\mathrm{NiFe} \mathrm{LDH}$ system, $\mathrm{Fe}^{3+}$ replaces partial $\mathrm{Ni}^{2+}$ sites in the $\mathrm{Ni}(\mathrm{OH})_{2}$ lattice, which results in the LDH lattice with positive charges, and consequently the anion $\mathrm{NO}_{3}{ }^{-}$must incorporate into the interlayers of the $\mathrm{LDH}$ to keep electric neutrality overall the LDH. The XPS spectrum of $\mathrm{N}$ 1s in Fig. $\mathrm{S} 9$ also confirms the presence of $\mathrm{NO}_{3}{ }^{-}$.

The OER electrocatalytic performance of the $\mathrm{NiFe}$ $\mathrm{LDH} / \mathrm{NF}$ was then carefully investigated in $1 \mathrm{~mol} \mathrm{~L}^{-1}$ $\mathrm{KOH}$ solution using a standard three-electrode system. And the OER activities of $\mathrm{Ni}(\mathrm{OH})_{2} / \mathrm{NF}, \mathrm{RuO}_{2} / \mathrm{NF}$ and NF alone were compared under similar measurements. As depicted in Fig. 3a, the polarization curves show that the $\mathrm{NiFe} \mathrm{LDH} / \mathrm{NF}$ exhibits the superior OER catalysis to the $\mathrm{Ni}(\mathrm{OH})_{2} / \mathrm{NF}$ and $\mathrm{RuO}_{2} / \mathrm{NF}$. Then, the chronoamperometry was measured to derive the potentials for OER in Fig. S10, revealing the NiFe LDH/NF with an extremely low potential of $\sim 1.411 \mathrm{~V} v s$. RHE to achieve the current density of $10 \mathrm{~mA} \mathrm{~cm}{ }^{-2}$ and a significantly low potential of $\sim 1.452 \mathrm{~V} v s$. RHE at a current density of $100 \mathrm{~mA} \mathrm{~cm}^{-2}$. In sharp contrast, the $\mathrm{Ni}(\mathrm{OH})_{2} / \mathrm{NF}, \mathrm{RuO}_{2} /$ $\mathrm{NF}$ and NF alone exhibit rather poor OER properties (Fig. S11). It is worth noting that the outperformance of $\mathrm{Ni}(\mathrm{OH})_{2} / \mathrm{NF}$ over $\mathrm{RuO}_{2} / \mathrm{NF}$ in OER electrocatalysis is attributed to the larger mass loading of $\mathrm{Ni}(\mathrm{OH})_{2} / \mathrm{NF}$ $\left(2.13 \mathrm{mg} \mathrm{cm}^{-2}\right)$ than that of $\mathrm{RuO}_{2} / \mathrm{NF}\left(0.25 \mathrm{mg} \mathrm{cm}^{-2}\right)$. Considering the surface area normalized polarization curves only reflect the overall activities, we further used mass activities to accurately elucidate the intrinsic activities of the catalysts. As shown in Fig. S12, the results suggest the outstanding OER performance of the NiFe LDH/NF. The superior OER activity of NiFe LDH/NF to $\mathrm{Ni}(\mathrm{OH})_{2} / \mathrm{NF}$ is owing to the $\mathrm{Fe}$ species in $\mathrm{NiFe}$ which plays an important role in enhancing OER catalytic properties under alkaline conditions [25-32].

To further understand the OER activity of these catalysts, the electrochemical double layer capacitance $\left(C_{\mathrm{dl}}\right)$ measurement was conducted to calculate the electrochemical active surface area (ECSA) according to the equation of ECSA $=C_{\mathrm{dl}} / C_{\mathrm{s}}\left(C_{\mathrm{s}}\right.$ denotes specific capaci- 

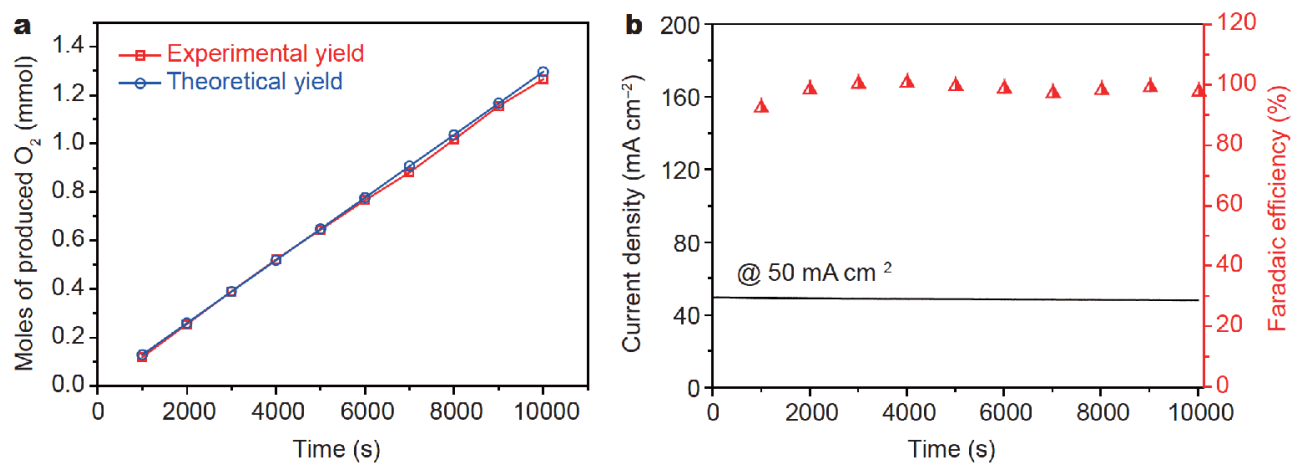

Figure 4 (a) The amount of generated $\mathrm{O}_{2}$ with NiFe LDH/NF electrode at different times with constant current densities of $50 \mathrm{~mA} \mathrm{~cm}^{-2}$ in $1 \mathrm{~mol} \mathrm{~L}$ $\mathrm{KOH}$. (b) The corresponding chronoamperometric curve and Faradaic efficiency.

tance and is $0.040 \mathrm{mF} \mathrm{cm}^{-2}$ in $\left.1 \mathrm{~mol} \mathrm{~L}^{-1} \mathrm{KOH}\right)[40,41]$. As shown in Fig. S13, the $C_{\mathrm{dl}}$ of $\mathrm{NiFe} \mathrm{LDH} / \mathrm{NF}, \mathrm{Ni}(\mathrm{OH})_{2} / \mathrm{NF}$ and $\mathrm{RuO}_{2} / \mathrm{NF}$ are $6.1,13.3$ and $5.4 \mathrm{mF} \mathrm{cm}^{-2}$, respectively. And the calculated ECSA of NiFe LDH/NF, $\mathrm{Ni}(\mathrm{OH})_{2} / \mathrm{NF}$ and $\mathrm{RuO}_{2} / \mathrm{NF}$ are $152.5,333.7$ and $135.0 \mathrm{~cm}^{2}$, respectively. It is noted that the ECSA of NiFe LDH/NF is smaller than that of $\mathrm{Ni}(\mathrm{OH})_{2} / \mathrm{NF}$, which is ascribed to the mass loading of $\mathrm{NiFe} \mathrm{LDH}$ much less than $\mathrm{Ni}(\mathrm{OH})_{2}$ to cause a lower roughness factor $[40,41]$. Then, the polarization curves are normalized by the ECSA in Fig. S14, also showing the superior OER activity of the NiFe LDH/ $\mathrm{NF}$ to the $\mathrm{Ni}(\mathrm{OH})_{2} / \mathrm{NF}$ and $\mathrm{RuO}_{2} / \mathrm{NF}$. In the cyclic voltammogram of NiFe LDH/NF (Fig. S15), an intense redox peak is observed, demonstrating that nickel oxyhydroxide $(\mathrm{NiOOH})$ were in situ generated on the surface of $\mathrm{NiFe}$ $\mathrm{LDH} / \mathrm{NF}$, which united with $\mathrm{Fe}$ species could provide prominent catalytic activity towards OER [33].

Furthermore, the corresponding Tafel plots calculated by polarization curves in Fig. $3 \mathrm{~b}$ illustrate that the NiFe LDH/NF yields a considerably small Tafel slope of $42.3 \mathrm{mV} \mathrm{dec}^{-1}$, which is smaller than those of $\mathrm{Ni}(\mathrm{OH})_{2} /$ $\mathrm{NF}\left(63.2 \mathrm{mV} \mathrm{dec}^{-1}\right)$ and $\mathrm{RuO}_{2} / \mathrm{NF}\left(70.1 \mathrm{mV} \mathrm{dec}{ }^{-1}\right)$, implying the rapid OER kinetics and efficient electron and mass transfer of the NiFe LDH/NF. EIS measurement was carried out to evaluate the kinetics of interfacial processes for these samples. The Nyquist plots present an obvious change of charge-transfer resistance $\left(R_{\mathrm{ct}}\right)$ of these samples at a constant potential. As presented in Fig. $3 c$, the NiFe $\mathrm{LDH} / \mathrm{NF}$ possesses the lowest $R_{\mathrm{ct}}(0.66 \Omega)$ among all these samples at potential of $1.48 \mathrm{~V}$, indicating the fastest charge transfer rate for OER of NiFe LDH/NF, which suggests the superior OER activities of the as-prepared $\mathrm{NiFe} \mathrm{LDH} / \mathrm{NF}$ to other samples. Additionally, durability is another significant criterion to evaluate the OER catalyst. In Fig. 3d, the chronoamperometric curve of NiFe $\mathrm{LDH} / \mathrm{NF}$ tested in $1 \mathrm{~mol} \mathrm{~L}^{-1} \mathrm{KOH}$ at $\sim 1.48 \mathrm{~V} v \boldsymbol{s}$. RHE without $i R$ correction illustrates that the current density had a decrease of about $20 \%$ after $20 \mathrm{~h}$ continuous measurement, which is attributed to the generated $\mathrm{O}_{2}$ bubbles covered on the electrode in OER. Moreover, the SEM images, XPS spectra and XRD pattern of the NiFe LDH/ NF after stability test in Figs S16-S19, present that the morphology and structure of the LDH are well preserved, further demonstrating the great durability of the $\mathrm{NiFe}$ $\mathrm{LDH} / \mathrm{NF}$ electrode. To present the structural recoverability of NiFe LDH/NF during electrocatalysis, the periodic galvanic pluses were investigated. In Fig. S20, the periodic galvanic pulses between 10 and $40 \mathrm{~mA} \mathrm{~cm}^{-2}$ exhibit that the current density was restorable, suggesting the great structural recoverability of NiFe LDH/NF during the catalytic OER process.

The Faradaic efficiency of the $\mathrm{NiFe}$ LDH/NF was measured in a gas-tight electrochemical cell in $1 \mathrm{~mol} \mathrm{~L}^{-1}$ $\mathrm{KOH}$. The theoretical yield of oxygen evolution was calculated by Faraday's law and assuming that four electrons were needed to produce one $\mathrm{O}_{2}$ molecule. When current density is fixed at $50 \mathrm{~mA} \mathrm{~cm}^{-2}$, comparing the experimental yield of the generated $\mathrm{O}_{2}$ with the theoretical yield, the amount of oxygen evolved is very close to its theoretical data in Fig. 4a and the corresponding Faradaic efficiency is derived up to 98\% (shown in Fig. 4b).

All the above data suggest that the as-prepared NiFe LDH/NF is highly efficient catalyst towards OER in terms of both catalytic activity and stability, which is superior to many other reported NiFe-based materials (shown in Table S1 and Fig. S21). This remarkable OER performance of the $\mathrm{NiFe} \mathrm{LDH} / \mathrm{NF}$ can be attributed to the following factors: 1) NF is highly conductive, which facilitates the electron transfer between the active $\mathrm{NiFe}$ $\mathrm{LDH}$ and Ni substrate; 2) porous NF offers larger specific surface area and active catalytic sites; 3 ) NiFe LDH has intrinsically excellent OER property [25-32]; 4) the ul- 
trathin NiFe LDH in situ grown on NF without surfactant on the surface benefits the electron transfer between the substrate and the active species and exposes more active sites; 5) the integrated $\mathrm{NiFe} \mathrm{LDH} / \mathrm{NF}$ as catalyst is robust and promises durable catalytic performance.

\section{CONCLUSIONS}

In summary, we have successfully fabricated NiFe LDH grown on $\mathrm{Ni}$ foam via a facile, green synthetic strategy at room temperature without extra energy consumption. The formation of the NiFe LDH follows a dissolutionprecipitation process, in which the acid conditions by hydrolysis of $\mathrm{Fe}^{3+}$ combined with $\mathrm{NO}_{3}^{-}$could etch the NF to form $\mathrm{Ni}^{2+}$. And then, the obtained $\mathrm{Ni}^{2+}$ were co-precipitated with the hydrolysed $\mathrm{Fe}^{3+}$ ions to in situ generate NiFe LDH film on the NF. In $1 \mathrm{~mol} \mathrm{~L}^{-1} \mathrm{KOH}$, the NiFe LDH/NF exhibits outstanding OER performance with a low potential of about $1.411 \mathrm{~V} v s$. RHE at current density of $10 \mathrm{~mA} \mathrm{~cm}^{-2}$, a small Tafel slope of $42.3 \mathrm{mV} \mathrm{dec}^{-1}$ and a significantly low potential of $\sim 1.452 \mathrm{~V} v s$. RHE at $100 \mathrm{~mA} \mathrm{~cm}^{-2}$ and superior catalytic stability. This simple and green synthetic strategy with no energy-input is environment-friendly and greatly reduces the cost of catalyst, and the as-prepared electrocatalyst offers splendid OER performance, making its grand feasibility in industrial applications.

Received 26 August 2018; accepted 16 September 2018; published online 15 October 2018

1 Holladay JD, Hu J, King DL, et al. An overview of hydrogen production technologies. Catal Today, 2009, 139: 244-260

2 Winter M, Brodd RJ. What are batteries, fuel cells, and supercapacitors? Chem Rev, 2004, 104: 4245-4270

3 Gong M, Zhou W, Tsai MC, et al. Nanoscale nickel oxide/nickel heterostructures for active hydrogen evolution electrocatalysis. Nat Commun, 2014, 5: 4695

4 Suntivich J, May KJ, Gasteiger HA, et al. A perovskite oxide optimized for oxygen evolution catalysis from molecular orbital principles. Science, 2011, 334: 1383-1385

5 Liang $\mathrm{Y}$, Li Y, Wang $\mathrm{H}$, et al. $\mathrm{Co}_{3} \mathrm{O}_{4}$ nanocrystals on graphene as a synergistic catalyst for oxygen reduction reaction. Nat Mater, 2011, 10: 780-786

6 Jiao F, Frei H. Nanostructured cobalt and manganese oxide clusters as efficient water oxidation catalysts. Energy Environ Sci, 2010, 3: $1018-1027$

7 Yagi M, Kaneko M. Molecular catalysts for water oxidation. Chem Rev, 2001, 101: 21-36

8 Gong M, Dai H. A mini review of NiFe-based materials as highly active oxygen evolution reaction electrocatalysts. Nano Res, 2014, 8: 23-39

9 Kanan MW, Nocera DG. In situ formation of an oxygen-evolving catalyst in neutral water containing phosphate and $\mathrm{Co}^{2+}$. Science, 2008, 321: 1072-1075

10 Han X, Yu C, Zhou S, et al. Ultrasensitive iron-triggered nanosized
Fe-CoOOH integrated with graphene for highly efficient oxygen evolution. Adv Energy Mater, 2017, 7: 1602148

11 Jiang Q, Xu L, Chen N, et al. Facile synthesis of black phosphorus: an efficient electrocatalyst for the oxygen evolving reaction. Angew Chem Int Ed, 2016, 55: 13849-13853

12 Yang $\mathrm{Y}$, Zhang $\mathrm{K}$, Lin $\mathrm{H}$, et al. $\mathrm{MoS}_{2}-\mathrm{Ni}_{3} \mathrm{~S}_{2}$ heteronanorods as efficient and stable bifunctional electrocatalysts for overall water splitting. ACS Catal, 2017, 7: 2357-2366

13 Xie J, Zhang J, Li S, et al. Controllable disorder engineering in oxygen-incorporated $\mathrm{MoS}_{2}$ ultrathin nanosheets for efficient hydrogen evolution. J Am Chem Soc, 2013, 135: 17881-17888

14 Zou X, Zhang Y. Noble metal-free hydrogen evolution catalysts for water splitting. Chem Soc Rev, 2015, 44: 5148-5180

15 Lin L, Zhu Q, Xu AW. Noble-metal-free Fe-N/C catalyst for highly efficient oxygen reduction reaction under both alkaline and acidic conditions. J Am Chem Soc, 2014, 136: 11027-11033

16 Gewirth AA, Varnell JA, DiAscro AM. Nonprecious metal catalysts for oxygen reduction in heterogeneous aqueous systems. Chem Rev, 2018, 118: 2313-2339

17 Sivanantham A, Ganesan P, Shanmugam S. Hierarchical $\mathrm{NiCo}_{2} \mathrm{~S}_{4}$ nanowire arrays supported on $\mathrm{Ni}$ foam: an efficient and durable bifunctional electrocatalyst for oxygen and hydrogen evolution reactions. Adv Funct Mater, 2016, 26: 4661-4672

18 Li Y, Hasin P, Wu Y. $\mathrm{Ni}_{x} \mathrm{Co}_{3-x} \mathrm{O}_{4}$ nanowire arrays for electrocatalytic oxygen evolution. Adv Mater, 2010, 22: 1926-1929

19 Gorlin Y, Jaramillo TF. A bifunctional nonprecious metal catalyst for oxygen reduction and water oxidation. J Am Chem Soc, 2010, 132: 13612-13614

20 Cui B, Lin $\mathrm{H}$, Li JB, et al. Core-ring structured $\mathrm{NiCo}_{2} \mathrm{O}_{4}$ nanoplatelets: synthesis, characterization, and electrocatalytic applications. Adv Funct Mater, 2008, 18: 1440-1447

21 Zhang J, Liu J, Xi L, et al. Single-atom Au/NiFe layered double hydroxide electrocatalyst: probing the origin of activity for oxygen evolution reaction. J Am Chem Soc, 2018, 140: 3876-3879

$22 \mathrm{Wu} \mathrm{L}, \mathrm{Li} \mathrm{Q}, \mathrm{Wu} \mathrm{CH}$, et al. Stable cobalt nanoparticles and their monolayer array as an efficient electrocatalyst for oxygen evolution reaction. J Am Chem Soc, 2015, 137: 7071-7074

23 Zou X, Huang X, Goswami A, et al. Cobalt-embedded nitrogenrich carbon nanotubes efficiently catalyze hydrogen evolution reaction at all pH values. Angew Chem Int Ed, 2014, 53: 4372-4376

24 Song F, Hu X. Ultrathin cobalt-manganese layered double hydroxide is an efficient oxygen evolution catalyst. J Am Chem Soc, 2014, 136: 16481-16484

25 Trotochaud L, Young SL, Ranney JK, et al. Nickel-iron oxyhydroxide oxygen-evolution electrocatalysts: the role of intentional and incidental iron incorporation. J Am Chem Soc, 2014, 136: 67446753

26 Qi J, Zhang W, Xiang R, et al. Porous nickel-iron oxide as a highly efficient electrocatalyst for oxygen evolution reaction. Adv Sci, 2015, 2: 1500199

27 Jiang J, Zhang C, Ai L. Hierarchical iron nickel oxide architectures derived from metal-organic frameworks as efficient electrocatalysts for oxygen evolution reaction. Electrochim Acta, 2016, 208: 17-24

28 Jiang J, Lu S, Wang WK, et al. Ultrahigh electrocatalytic oxygen evolution by iron-nickel sulfide nanosheets/reduced graphene oxide nanohybrids with an optimized autoxidation process. Nano Energy, 2018, 43: 300-309

29 Song B, Li K, Yin Y, et al. Tuning mixed nickel iron phosphosulfide nanosheet electrocatalysts for enhanced hydrogen and oxygen evolution. ACS Catal, 2017, 7: 8549-8557 
30 Yin $\mathrm{S}, \mathrm{Tu} \mathrm{W}$, Sheng $\mathrm{Y}$, et al. A highly efficient oxygen evolution catalyst consisting of interconnected nickel-iron-layered double hydroxide and carbon nanodomains. Adv Mater, 2018, 30: 1705106

31 Yu L, Yang JF, Guan BY, et al. Hierarchical hollow nanoprisms based on ultrathin $\mathrm{Ni}-\mathrm{Fe}$ layered double hydroxide nanosheets with enhanced electrocatalytic activity towards oxygen evolution. Angew Chem Int Ed, 2018, 57: 172-176

32 Jia Y, Zhang L, Gao G, et al. A heterostructure coupling of exfoliated $\mathrm{Ni}$-Fe hydroxide nanosheet and defective graphene as a bifunctional electrocatalyst for overall water splitting. Adv Mater, 2017, 29: 1700017

33 Liu J, Zheng Y, Wang Z, et al. Free-standing single-crystalline NiFe-hydroxide nanoflake arrays: a self-activated and robust electrocatalyst for oxygen evolution. Chem Commun, 2018, 54: 463-466

34 Gong M, Li Y, Wang H, et al. An advanced Ni-Fe layered double hydroxide electrocatalyst for water oxidation. J Am Chem Soc, 2013, 135: 8452-8455

35 Chen X, Gao P, Liu H, et al. In situ growth of iron-nickel nitrides on carbon nanotubes with enhanced stability and activity for oxygen evolution reaction. Electrochim Acta, 2018, 267: 8-14 $\mathrm{Xu} \mathrm{K}$, Gilles T, Breit B. Asymmetric synthesis of $\mathrm{N}$-allylic indoles via regio- and enantioselective allylation of aryl hydrazines. Nat Commun, 2015, 6: 7616

37 Chi J, Yu H, Qin B, et al. Vertically aligned $\mathrm{FeOOH} / \mathrm{NiFe}$ layered double hydroxides electrode for highly efficient oxygen evolution reaction. ACS Appl Mater Interfaces, 2017, 9: 464-471

38 Tang C, Wang HS, Wang HF, et al. Spatially confined hybridization of nanometer-sized nife hydroxides into nitrogen-doped graphene frameworks leading to superior oxygen evolution reactivity. Adv Mater, 2015, 27: 4516-4522

39 Stupnišek-Lisac E, Karšulin M. Electrochemical behaviour of nickel in nitric acid. Electrochim Acta, 1984, 29: 1339-1343

40 McCrory CCL, Jung S, Peters JC, et al. Benchmarking heterogeneous electrocatalysts for the oxygen evolution reaction. J Am Chem Soc, 2013, 135: 16977-16987

41 McCrory CCL, Jung S, Ferrer IM, et al. Benchmarking hydrogen evolving reaction and oxygen evolving reaction electrocatalysts for solar water splitting devices. J Am Chem Soc, 2015, 137: 4347-4357

Acknowledgements This work was financially supported by the National Natural Science Foundation of China (21425103 and 21501192).

Author contributions Wang Q designed and engineered the experiments; Yang $\mathrm{H}$ performed the experiments, analyzed the data and wrote the paper with support from Wang C, and Zhang Y. All authors contributed to the general discussion.

Conflict of interest The authors declare no conflict of interest.

Supplementary information Supporting data are available in the online version of the paper. 

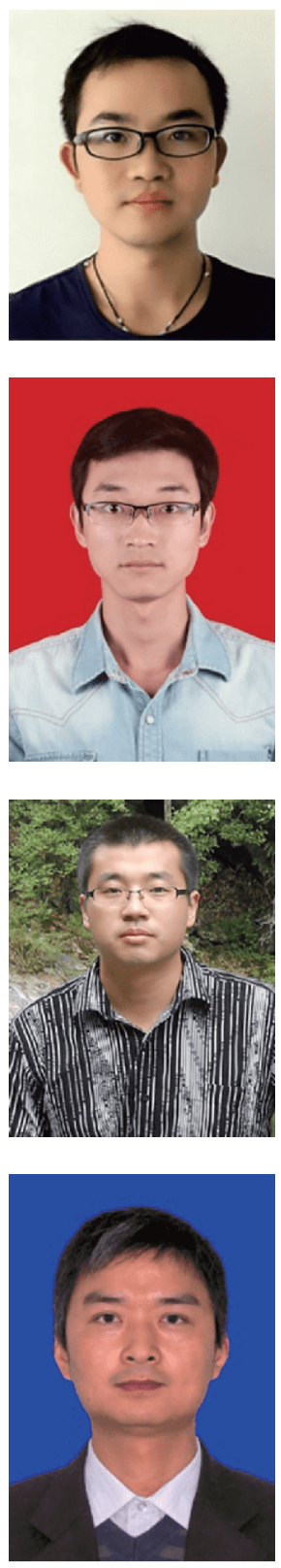

Hongchao Yang is a PhD candidate in Suzhou Institute of Nano-Tech and Nano-Bionics, Chinese academy of sciences. His current research focuses on the electrocatalysis for hydrogen evolution, oxygen reduction/evolution reaction.

Changhong Wang received his BSc degree from Zhengzhou University in 2014. Currently, he is a $\mathrm{PhD}$ candidate in Suzhou Institute of Nano-Tech and Nano-Bionics, Chinese Academy of Sciences under the supervision of Prof. Qiangbin Wang since 2014. His research interest is focused on the metal-carbon-based functional materials for electrocatalysis.

Yejun Zhang is a research assistant professor in the Division of Nanobiomedicine at Suzhou Institute of Nano-Tech and Nano-Bionics, Chinese Academy of Sciences. His current research mainly focuses on the synthesis of semiconductor nanocrystals and their applications in optoelectronics and fluorescence imaging.
Qiangbin Wang is the Director of the Key Laboratory of Nano-Bio Interface, Chinese Academy of Sciences and Professor in nano chemistry at Suzhou Institute of Nano-Tech Nano-Bionics, Chinese Academy of Sciences. His research interest concentrates on controlled synthesis and self-assembly of inorganic nanocrystals and their applications in optoelectronics and catalysis.

\section{室温绿色合成镍铁层状双氢氧化物/泡沫镍及其高效的电催化析氧反应性能}

杨红超 ${ }^{1,2}$, 汪昌红 ${ }^{1,2}$, 张叶俊 ${ }^{2}$, 王强斌 ${ }^{1,2^{*}}$

摘要 绿色能源技术如电解水和燃料电池等由于其无污染的特点, 近年来一直受到人们的广泛关注. 然而, 在合成其催化剂的过程中多会 消耗化石能源, 从而造成环境污染, 形成恶性循环. 因此, 在无额外能量输入的条件下合成高效的电催化剂是非常必要的, 但同时又充满挑 战. 本文通过简单的一步合成法在室温下制备了一种具有高效析氧催化性能的镍铁层状双氢氧化物/泡沫镍 $(\mathrm{NiFe} \mathrm{LDH} / \mathrm{NF})$ 催化剂. NiFe $\mathrm{LDH}$ 的形成遵循溶解-沉淀机理: $\mathrm{Fe}^{3+}$ 水解产生的酸性环境联合 $\mathrm{NO}_{3}{ }^{-}$, 刻蚀泡沫镍表面, 形成 $\mathrm{Ni}^{2+}$, 随后, $\mathrm{Ni}^{2+}$ 与水解的 $\mathrm{Fe}$ 物种原位共沉淀于 泡沫镍表面, 生成 NiFe LDH. 所得到的 NiFe LDH/NF在碱性环境下, 表现出高效的电催化析氧反应性能. 在 $1 \mathrm{~mol} \mathrm{~L}^{-1}$ 的氢氧化钾溶液中, 当 电流密度为 $10 \mathrm{~mA} \mathrm{~cm}^{-2}$ 时, 其电位低至 $1.411 \mathrm{~V} v \mathrm{~s}$. RHE, 相应的塔菲尔斜率仅为 $42.3 \mathrm{mV} \mathrm{dec}{ }^{-1}$, 而在电流密度为 $100 \mathrm{~mA} \mathrm{~cm}$ 时, 所需电位 也仅为 $1.452 \mathrm{~V} v s$. RHE. 此外, 该材料还表现出卓越的结构稳定性. 这种绿色制备 NiFe LDH/NF的合成方法有望在OER催化中得到广泛的 应用. 